\title{
Determination of Sharia Stock Price through Analysis of Fundamental Factors and Macro Economic Factors
}

\author{
Taufiq Akbar ${ }^{1}$, Adam Afiezan ${ }^{2}$ \\ ${ }^{1,2}$ Faculty of Economics and Business, Perbanas Institute, Jakarta, Indonesia \\ Corresponding Author: Taufiq Akbar \\ Faculty of Economics and Business, Perbanas Institute, Jakarta, Indonesia
}

\begin{abstract}
This study aims to analyze and obtain empirical evidence regarding the influence of corporate fundamental and macroeconomic factors on Islamic stock prices listed in the Jakarta Islamic Index (JII). The company's fundamental information is taken from the company's financial statements on the Indonesia Stock Exchange from 2012 to 2016 and Macro Economic Data taken from the official website of the Indonesian Central Statistics Agency. The method of selecting samples used was purposive sampling. The study results were fundamental factors such as Earning per Share (EPS), Return on Assets (ROA), Debt to Equity Ratio (DER) and Exchange Rate significantly influences stock prices. On the other hand, the interest rate has no significant effect on stock prices. The model studied shows that the influence of independent variables on the dependent variable is high, namely $73.4 \%$. It meansother factors that can affect stock prices outside the variables studied are worth $26.6 \%$.
\end{abstract}

Key Words: Stock Price, Fundamental Factor, Macro Economic Factor.

\section{INTRODUCTION}

The era of globalization forms different behaviors for humans in carrying out activities. One form of innovation in the era of globalization is the way humans carry out investment. Previously, investments tend to be made in the real sector such as investment in land and precious metals. However, now there are other alternatives in investing, namely share investment in the Capital Market. Investment in capital market is means to invest their money in securities(Luhukay, Mangantar, Baramuli, 2016).

As a country that has a majority population of Muslims, Indonesia should provide investment instruments based on the needs of its population. In terms of investment activities, Muslim communities should not make investments that are contrary to sharia principles. Therefore, Indonesia through Bapepam-LK has issued a sharia capital market regulation package in 2006 and a list of sharia securities in 2007 (www.ojk.go.id). With those lists, the community will be easier to know which stocks have fulfilled the sharia element.

The launch of the Jakarta Islamic Index (JII) in 2000 and the sharia online trading system in 2011 impacted the increase in Islamic stock trading in Indonesia. The number of shares that entered the category of sharia continued to increase, but from 2012 to 2016 the shares included in the sharia category showed a horizontal trend which was in the range of 304 to 306 shares as shown in the following figure:
Figure 1. Sharia Stock Development

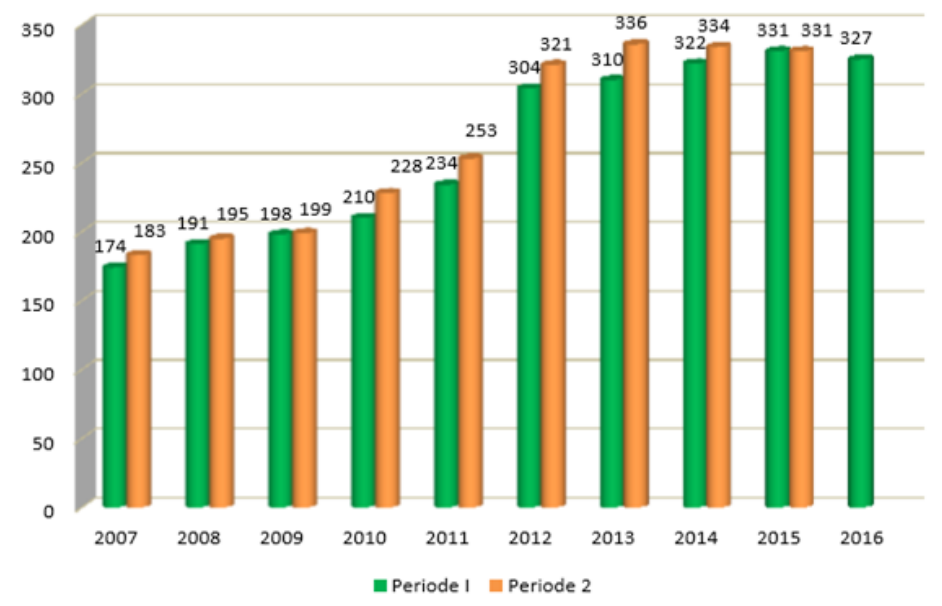

Source: www.ojk.go,id

As with conventional stock price movements, Islamic stock prices are also not much different(Setiawan and Oktariza, 2013). Share prices can be influenced by various factors both from the internal side of the company such as fundamental factors and external factors such as the company's macroeconomic factors. Several studies have been conducted in this regard, in terms of fundamental factors, the results are found that Earning Per Share (EPS), Return on Assets (ROA) and Debt to Equity Ratio (DER) affect stock prices (Manoppo, 2015). However, some other studies have different results where EPS, ROA and DER have no effect on stock prices (Anita and Yadav, 2014), (Saragih, 2018). 
As researches in fundamental factor above, there is contradiction result in macro economics. The result of the researches said that stock price changes are influenced by macro economic factors such as the exchange rate, interest rate and Gross Domestic Product (GDP)(Mulyani, 2014). However, there are also research results which state that these three variables do not significantly influence stock prices (Chirchir, 2014), (Suriani, Kumar, Jamil, Muneer, 2015), (Giri and Joshi, 2017).

Because stockis investment instruments that provide high returns, but stockis also risky, it requires knowledge about the factors that can influence stock price movements. In addition, it is interesting to study that there are inconsistencies in the results of previous studies regarding the influence of fundamental variables and macroeconomic factors on stock prices as explained in the background above.

Due to the importance of knowledge about factors that can affect the stock price that should be known by Indonesian Muslim investors and there were also the inconsistency results of the previous research, it makes researchers interested in conducting research on the effect of fundamental variables and macroeconomic variables on Islamic stock prices listed on the Jakarta Islamic Index.

\section{MATERIAL AND METHOD}

The Islamic capital market in Indonesia has been developing since 1997 which was marked by the launch of Islamic mutual funds. Since then, Indonesia's sharia capital market has continued to grow and develop, which is marked by the increasing number of Islamic products, the issuance of regulations related to the sharia capital market and the increasing number of people who know and care about the Islamic capital market. The development of the Islamic capital market should be appreciated. However, the market share of Islamic products in the capital market is still relatively small;therefore, a strategy is needed to increase the market share of Islamic products. One of them is an increase in investment knowledge in Islamic stocks.

Changes in the stock price can be influenced by several factors, including internal factors such as the company's fundamental factors and external factors such as a company's macroeconomic factors. Fundamental factors can show the company's financial performance and can also show the company stock performance, while, macroeconomic factors can affect the company's performance. In this study the performance of Islamic stocks in Indonesia will be analyzed using these two factors.

\section{The Effect of EPS on Sharia Stocks}

Increased EPS indicates that the company has succeeded in increasing the level of investor prosperity. This encourages investors to increase the amount of capital invested in the company's shares. An increase in the number of requests for stocks has pushed up share prices (Idawati and Wahyudi, 2015), (Kumar, 2017). Thus if EPS increases, the market will respond positively by following the increase in stock prices.

\section{The Effect ROA on Sharia Stocks}

ROA is a ratio that measures the ability of a company's assets to generate profits. The higher the ROA value is, the higher the company's ability is to generate profits. Improving company performance as indicated by ROA can be used as a positive signal for the company's performance in the future. Therefore, an increase in ROA will affect the increase in stock prices (Nurhakim, Anistia S. Yunita, Irni. Iradianty, 2016), (Purnamawati, 2016). With assuming that the company's performance shows good company performance, so the company's stock price will increase.

\section{The Effect of DER on Sharia Stocks}

DER is a ratio that measures the level of leverage against equity owned by a company. A high DER signifies a high proportion of the company's asset funding through debt. The high level of debt can cause the increse of company's interest expense and it results in a decrease in the level of profit. Therefore, the high value of DER can be a negative signal for the company's performance and a decrease in investor interest in the stock which will cause decreasing of the stock price (Dadrasmoghadam and Akbari, 2015), (Ghi and $\mathrm{Ba}, 2015)$.

\section{The Effect of Exchange Rate on Sharia Stocks}

Fluctuations in the rupiah exchange rate will cause some impacts on the economy. The impactsare usually in terms of rising commodity prices in the real sector, reduced number of domestic savings, and many other impacts. This will cause people's purchasing power to decline and it is likely that investors will withdraw their funds to meet their needs. The decline in investment in the capital market will cause stock prices to decline (Mgammal, 2012), (Anggarwal, Priyanka. Saqib, 2017). This is caused by a decrease in demand or interest in investing.

\section{The Effect Interest Rate on Sharia Stocks}

A high interest rate can be a cause of investors transferring their investment instruments from stocks to deposits or other instruments. This is because deposits have a smaller risk than stocks. The decline in interest in investment in shares can affect stock prices. Where, when the demand for shares decreases will cause the stock price will also decline (Mulyani, 2014), (Shuangqun, 2017).

\section{The Effects GDP on Sharia Stocks}

GDP is a picture of a country's economic growth. The high value of GDP signifies a better economic growth of a country. In this case, if the increase in GDP is a sign that the purchasing power of the people is also increasing. When the purchasing power of the people increases, the tendency of people to save and invest is higher. Therefore, increasing GDP can be accompanied by an increase in stock prices due to the increasing demand for share prices (Ayopo, Isola and Olukayode, 2016). 


\section{Research Design}

This type of research is pure research which aims to verify the acceptance of existing theories and find out more about a concept (Abdillah, W. Hartono, 2015). The approach used is a quantitative approach by examining certain populations and samples with quantitative / statistical analysis aimed at testing predetermined hypotheses (Jogianto, 2010).

\section{Types of Data, Place and Time of Research}

The data used in this research is secondary data. Secondary data is data obtained from existing sources. Secondary data can be in the form of reports, publications, books, and so on.
The data taken from this research are stock price data, financial statements, Interest Rate, Exchange Rate and Gross Domestic Product at the end of each period starting from 2012 to 2016.

\section{Data Observed}

Research observations are aimed at a set of independent variables, namely fundamental and the macroeconomic factors to the dependent variable, namely the changes in the price of Islamic stocks included in the Jakarta Islamic Index. The following is explained the definition of the observed variable:

Table 1. Observed Variables

\begin{tabular}{|c|c|c|c|}
\hline Variables & Variable Concept & Indicator & Source \\
\hline Stock price & $\begin{array}{l}\text { Prices are formed due to stock offers } \\
\text { and requests from sellers and buyers. }\end{array}$ & Closing price at the end of the year. & $\begin{array}{l}\text { (Suparningsih, } \\
\text { 2017) }\end{array}$ \\
\hline $\begin{array}{l}\text { Earning per Share } \\
\text { (EPS) }\end{array}$ & $\begin{array}{l}\text { Ratio to analyze the ability of } \\
\text { companies to generate profits based } \\
\text { on shares owned. }\end{array}$ & $=\frac{\text { Revenue After Tax }}{\text { Number of outstanding Share }}$ & $\begin{array}{c}\text { (Bratamanggala, } \\
\text { 2018) }\end{array}$ \\
\hline $\begin{array}{l}\text { Return on Assets } \\
\text { (ROA) }\end{array}$ & $\begin{array}{l}\text { Ratios that show the ability of the } \\
\text { capital invested in total assets in } \\
\text { generating profits. }\end{array}$ & ROA $=\frac{\text { Profit Before Tax }}{\text { Total Assets }}$ & $\begin{array}{c}\text { (Bratamanggala, } \\
\text { 2018) }\end{array}$ \\
\hline $\begin{array}{l}\text { Debt to Equity } \\
\text { Ratio (DER) }\end{array}$ & $\begin{array}{l}\text { Ratios that show the percentage of } \\
\text { funds provided by shareholders to } \\
\text { lenders. }\end{array}$ & $\mathrm{DER}=\frac{\sum \text { Debt }}{\sum \text { Shareholder Equity }}$ & $\begin{array}{l}\text { (Purnamawati, } \\
\text { 2016) }\end{array}$ \\
\hline Exchange Rate & Rupiah exchange rate against dollar. & $\begin{array}{l}\text { Rupiah Exchange Rate against Dollar } \\
\text { at the end of the year }\end{array}$ & (Mulyani, 2014) \\
\hline $\begin{array}{l}\text { Tingkat Suku } \\
\text { Bunga }\end{array}$ & $\begin{array}{l}\text { The Policy of interest rates that } \\
\text { reflect the monetary policy stance set } \\
\text { by Bank Indonesia and announced to } \\
\text { the Public. }\end{array}$ & $\begin{array}{l}\text { Bank Indonesia Interest Rate at the } \\
\text { end of the research observation period }\end{array}$ & (Mulyani, 2014) \\
\hline $\begin{array}{l}\text { Gross Dosemtic } \\
\text { Product (GDP) }\end{array}$ & $\begin{array}{l}\text { The total value of production of } \\
\text { goods and services within a country } \\
\text { for one year. }\end{array}$ & $\begin{array}{l}\text { the value of Gross Domestic Product } \\
\text { at the end of the observation period. }\end{array}$ & (Mulyani, 2014) \\
\hline
\end{tabular}

Source: Taken from previous researchers

\section{Data Collection Technique}

Population is the object of research that has certain qualities and characteristics set by researchers to be studied and then drawn conclusions (Sugiyono, 2012). The population in this study were all syaria stocks that entered the Jakarta Islamic Index on the Indonesia Stock Exchange. Semple was chosen by using purposive sampling technique that is the selection of samples based on certain criteria (Jogianto, 2010). The criteria used in purposive sampling are as follows:

a) Sharia Share Price Data included in the Jakarta Islamic Index on shares listed on the Indonesia Stock Exchange for the period 2012 to 2016. Data obtained from the official website of the Indonesia Stock Exchange (www.idx.co.id).

b) Financial report data included in the Jakarta Islamic Index on shares listed on the Indonesia Stock Exchange in the 2012 to 2016 period obtained from the official website of the Indonesia Stock Exchange (www.idx.co.id). c) End of year data from the Interest Rate, Exhange Rate and Gross Domestic Gross for the 2012 to 2016 period obtained from the Indonesian Statistics Agency (www.bps.go.id)

\section{Data analysis}

The data analysis was carried out by first testing the classical assumptions which is by testing normality, multicollinearity, heterocedasticity and autocorrelation. After the data analyzed meets the requirements of the classical assumption test then hypothesis testing is done by doing $\mathrm{t}$ test, $\mathrm{f}$ test and determination coefficient.

\section{RESULTS}

The results of this research are the results of the second data processing. The first data obtained the multicollinearity of the exchange rate and GDP variables. This means, there is a high correlation between the two variables. Therefore, in this study research only uses one of them. The variable 
chosen to apply in this study is the exchange rate variable. With these changes produce a better model. This is evidenced by the increasingly large coefficient of determination (R2) which was previously worth $64 \%$ changed to $71 \%$. This is reinforced by the results of previous research which states that there is a significant effect of the exchange rate variable on the GDP variable (Kganyago and Gumbo, 2015).

\section{Classic assumption testing \\ Normality testing}

Normality test is done to see whether the independent and dependent variables have normal distribution or not. Testing the normality of data in this study uses the normal P-Plot graph method of Standardized residual cumulative probability, by identifying if the distribution is around the normal line, it can be concluded that the independent and dependent variables are normally distributed. Results from the normal P-plot graph can be seen in the following figure:

Figure 2. Test Results for Normality Assumptions with P-plots.

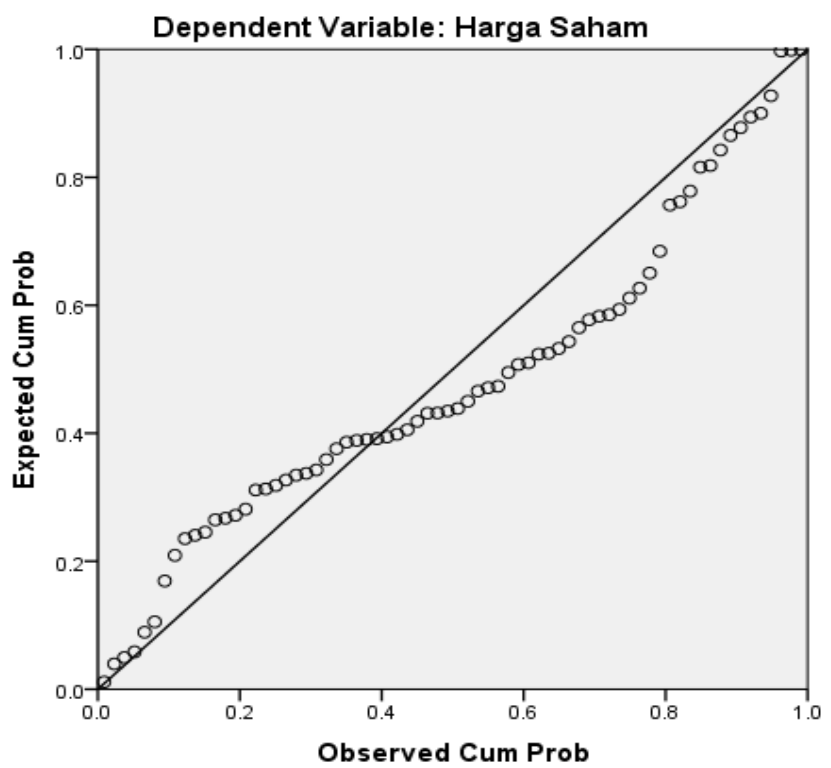

Source: Processed by SPSS (2018)

On the P-Plot chart above, it can be seen that the points spread on the diagonal line. The graph shows that the regression model is feasible to use because it meets the assumption of normality or in other words that the regression model can be continued.

\section{Multicollinearity Testing}

Multicollinearity testing aims to test whether the regression model found correlation between independent variables. A good regression model should not correlate between independent variables. Multicollinearity can be seen from the tolerance value and Variance Inflation Factor (VIF). If the VIF value is greater than 10 and the tolerance value is less than 0.1 , multicollinearity will occur and the regression model is suitable for use. The tolerance calculation results and VIF can be known in the table below:
Tabel 2. Multicollinearity Test Results

\begin{tabular}{|ll|c|c|}
\hline \multirow{2}{*}{ Model } & \multicolumn{2}{|c|}{ Collinearity Statistics } \\
\cline { 3 - 4 } & & Tolerance & VIF \\
\hline 1 & (Constant) & & \\
& EPS & .863 & 1.159 \\
& ROA & .722 & 1.386 \\
& DER & .788 & 1.269 \\
& Exchange_Rate & .921 & 1.089 \\
& Interest_Rate & .960 & 1.042 \\
\hline
\end{tabular}

Source: Processed by SPSS (2018)

From the table above shows that all independent variables have a tolerance value above 0.1 and the VIF value is below the number 10. This indicates that the independent variables used in this study do not show the presence of multicollinearity so that the regression model is feasible for testing hypotheses.

\section{Heteroscedasticity Testing}

Heteroscedasticity testing aims to test whether in the regression model there is a variance inequality from residual one observation to another observation. Scatterplot can be used to test this, where the $\mathrm{X}$ axis is the ZPRED predictive values $=$ Regression Standardized Predicted Value with the $\mathrm{Y}$ axis is the ZRESID = Regression Standardized Predicted Value value. If the graph obtained shows that there are certain patterns produced by the existing points, it is said to occur heteroscedasticity, but if it does not form a particular pattern, it is said that heteroscedasticity does not occur. Heteroscedasticity test results can be seen in the picture below:

\section{Figure 3. Heteroscedasticity Test Results}

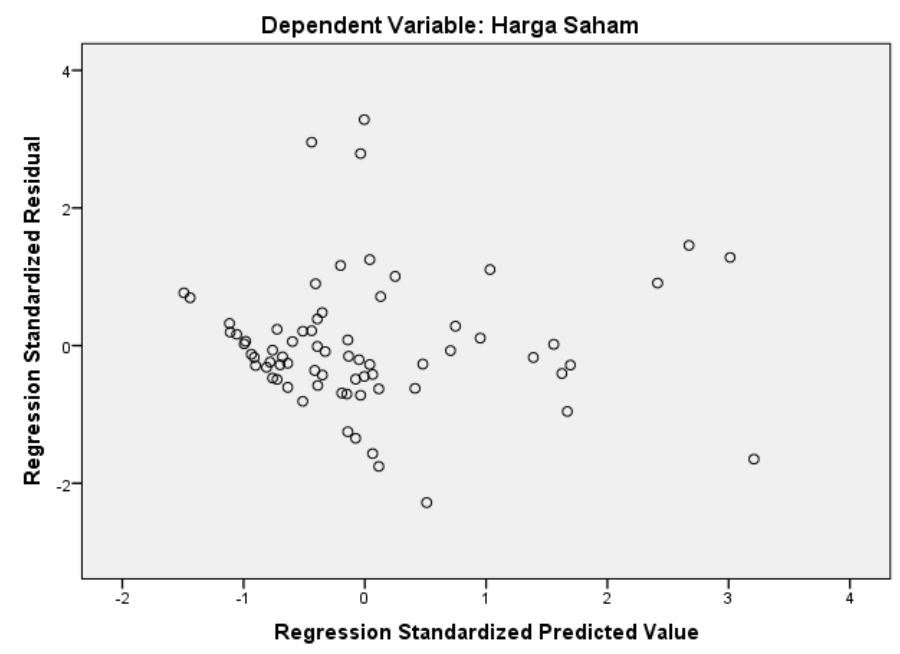

Source: Processed by SPSS (2018)

From the results of the heteroscedasticity test above, it can be seen that the scatterplot points above do not form a particular pattern. This shows that the regression model is not exposed to heteroscedasticity. 


\section{Autocorrelation Testing}

Autocorrelation testing aims to test whether in a linear regression model there is a correlation between sample members sorted by time. A good regression model is free from autocorrelation. To test the presence or absence of correlation can be done through testing of the value of Durbin Watson. The results of the autocorrelation test can be seen in the following table:

Table 3.Autocorrelation Test Results

\begin{tabular}{|c|c|c|c|c|c|}
\hline Model & $\mathrm{R}$ & $\begin{array}{c}\mathrm{R} \\
\text { Square }\end{array}$ & $\begin{array}{c}\text { Adjusted R } \\
\text { Square }\end{array}$ & $\begin{array}{c}\text { Std. Error } \\
\text { of the } \\
\text { Estimate }\end{array}$ & $\begin{array}{c}\text { Durbin- } \\
\text { Watson }\end{array}$ \\
\hline 1 &, $857^{\mathrm{a}}$ &, 734 &, 713 & 4889,7284 &, 658 \\
\hline
\end{tabular}

Source: Processed by SPSS (2018)

From the results of the autocorrelation test aboveshows that the value of Durbin-Watson is equal to 0.658. Means, the Durbin-Watson value is between -2 and 2. This result shows that the regression model used by the researcher does not experience autocorrelation problems.

\section{Hypothesis testing \\ Individual Parameter Testing (t test)}

The results of the statistical t-test show how far the influence of one independent variable individually in explaining the variation of the dependent variable. It is also used to determine whether the is influence of each independent variable individually on the dependent variable at the 0.05 significance level.

Table 4. Individual Parameter Test Results

\begin{tabular}{|c|c|c|c|c|c|}
\hline Variabel & $\mathrm{t}$ \\
& $\mathrm{t}$ table & Pengaruh & & Signifikansi \\
\hline EPS & 9,455 & 1,669 & Berpengaruh &, 000 & Signifikan \\
ROA & 3,667 & 1,669 & Berpengaruh &, 001 & Signifikan \\
DER & 4,508 & 1,669 & Berpengaruh &, 000 & Signifikan \\
Exchange & 2,741 & 1,669 & Berpengaruh &, 008 & Signifikan \\
Rate & & 1,669 & Tidak &, 952 & Tidak \\
Interest & 0,069 & & & & \\
Rate & & & & & \\
\hline
\end{tabular}

Source: Processed by SPSS (2018).

From the table above it can be conclude that the variables EPS, ROA, DER, and Exchange Rate have $t$ count values greater than $t$ table values. Therefore we can conclude that individually only EPS, ROA, DER, and Exchange Rate affect stock price movements. In addition, it can be seen that the influence of EPS, ROA, DER, and Exchange Rate on stock prices has a high level of confidence, this is indicated by the sig value of EPS, ROA, DER, and Exchange Rate smaller than 0.05 . While the interest rate does not have a significant effect on stock prices as indicated by the value of $\mathrm{t}$ count is smaller than $\mathrm{t}$ table while the confidence level is above 0.05 .

\section{Simultaneous Testing (f Test)}

Simultaneous effect test is used to show that the independent variables simultaneous affect the dependent variable. The result of the f test in the study is seen in the table below:

Table 5. Simultaneous Test Results Table (Test f)

\begin{tabular}{|c|c|c|c|c|}
\hline f hitung & f table & Pengaruh & Sig. & Signifikansi \\
\hline 35,287 & 2,35 & Berpengaruh &, 000 & Signifikan \\
\hline
\end{tabular}

Source: Processed by SPSS (2018).

From these results it can be concluded that the f count is greater than $f$ table. While for the level of significance the $f$ test has a significance level of 0.000 or less than 0.050 . Based on these results, the EPS, ROA, DER, Exchange Rate and Interest Rate have a significant effect simultaneously on stock prices.

\section{Coefficient Determination Testing}

The coefficient of determination is used to measure how much the percentage of the variation of the independent variables in the multiple linear regression model on the dependent variable. The coefficient of determination is between zero and one. The results of the calculation of the coefficient of determination (R2) in this study are presented in the table below:

Table 6. Determination Coefficient Test Results

\begin{tabular}{|c|c|c|c|c|c|}
\hline Model & $\mathrm{R}$ & $\begin{array}{c}\mathrm{R} \\
\text { Square }\end{array}$ & $\begin{array}{l}\text { Adjusted } \\
\text { R Square }\end{array}$ & $\begin{array}{c}\text { Std. Error } \\
\text { of the } \\
\text { Estimate }\end{array}$ & $\begin{array}{l}\text { Durbin- } \\
\text { Watson }\end{array}$ \\
\hline 1 &, $857^{\mathrm{a}}$ & ,734 & ,713 & 4889,7284 & ,658 \\
\hline
\end{tabular}

Source: Processed by SPSS (2018).

From the results of the SPSS process in the table above shows the value of Adjusted R Square is 0.713 or $73.4 \%$. This means, the independent variables of the model studied have a contribution of influence as much as $73.4 \%$. While there are other variables that affect prices outside of the variables studied by $73.4 \%$.

\section{CONCLUSION}

Based on the results of the study, it is known that during the period of observation the factors influencing stock prices are EPS, ROA, DER, and Exchange Rate which affect individually on stock prices. This is in accordance with the hypothesis formulated earlier and the results of several previous researchers. But in this case the interest rate is not proven to affect stock prices. This proves that the interest rate cannot influence the decision of stock investors to invest or change the financial instruments of investors from stock investments to deposit or other instruments affected by interest rates, and otherwise.

This study also proves that there is a high correlation between the variable exchange rate and the GDP variable. This may occur because transactions such as buying or selling from a national scale company during the 
observation period are strongly influenced by the rupiah exchange rate against the dollar. Therefore, the exchange rate can affect the national business climate and economic growth as indicated by the value of GDP (di Giovanni and Shambaugh, 2008). Therefore, in this study, the exchange rate variable was chosen as the observed variable.

Based on the coefficient of determination valued at $73.4 \%$, it shows that the independent variables studied have a high proportion in predicting stock prices. Thus, this study suggest to investors to pay attention to the value of the variables studied in investing in the capital market in Indonesia. Then the next researcher is expected to make the exchange rate and GDP variables as separate variables, namely as independent and dependent variables, or use GDP as an intervening variable in predicting the effect of exchange rates on stock prices.

\section{Acknowledgement}

This research was conducted because of the support of many things such as the Indonesian government in this case the Ministry of Research, Technology and Higher Education of the Republic of Indonesia (KEMENRISTEK DIKTI) and Perbanas Institute as the main support in terms of material and other supports in conducting the research. The researcher expressed thanks to the Indonesia Stock Exchange and the Central Statistics Agency and other parties for providing information to the public in obtaining the required data.

\section{BIBLIOGRAPHY}

1. Abdillah, W. Hartono, J. (2015) Partial Least Square (PLS): Alternatif Structural Equation Modelling (SEM) dalam Penelitian Bisnis. Yogyakarta: Andi Offset.

2. Anggarwal, Priyanka. Saqib, N. (2017) 'Impact of macro economic variables on stock market in India', International Journal of Economics and Financial Issues, 7(4), pp. 10-14.

3. Anita and Yadav, P. (2014) 'Influence of Selected Financial Indicators on Stock Price of Tata Motors LTD', International journal of application or inovation in engineering management, 3(7), pp. 249-252. doi: ISSN 2319 - 4847.

4. Ayopo, B. A., Isola, L. A. and Olukayode, S. R. (2016) 'Stock Market Response to Economic Growth and Interest Rate Volatility: Evidence from Nigeria', 6(1), pp. 354-360.

5. Bratamanggala, R. (2018) 'The factors affecting board stock price of Lq45 stock exchange 20122016: Case of Indonesia', European Research Studies Journal, 21(1), pp. 115-124.

6. Chirchir, D. (2014) 'The Relationship between Share Prices and Interest Rates: Evidence from Kenya', Journal of Finance and Investment Analysis, 3(2), pp. 91-98.doi: 10.1007/BF02296425.
7. Dadrasmoghadam, A. and Akbari, S. M. R. (2015) 'Relationship between Financial Ratios in the Stock Prices of Agriculture-Related Companies Accepted On the Stock Exchange for Iran', Research Journal of Fisheries and Hydrobiology, 10(9), pp. 586-591.

8. Ghi, T. N. and Ba (2015) 'The Impact of Capital Structure and Financial Performance on Stock Returns of the Firms in Hose', International Journal of Information Research and Review, 2(6), pp. 734737.

9. Di Giovanni, J. and Shambaugh, J. C. (2008) 'The impact of foreign interest rates on the economy: The role of the exchange rate regime', Journal of International Economics, 74(2), pp. 341-361. doi: 10.1016/j.jinteco.2007.09.002.

10. Giri, A. K. and Joshi, P. (2017) 'The Impact of Macroeconomic Indicators on Indian Stock Prices: An Empirical Analysis', Studies in Business and Economics, 12(1), pp. 61-78. doi: 10.1515/sbe2017-0005.

11. Idawati, W. and Wahyudi, A. (2015) 'Effect of Earning Per Share (EPS) and Return On Assets (ROA) Against Share Price on Coal Mining Company Listed in Indonesia Stocks Exchange', Journal of Resource Development and Management, 7(June 2016), pp. 79-92.

12. Jogianto (2010) Metodologi Penelitian Bisnis: Salah Kaprah dan Pengalaman-Pengalaman. Yogyakarta: BPFE UGM.

13. Kganyago, T. and Gumbo, V. (2015) 'An Empirical Study of the Relationship between Money Market Interest Rates and Stock Market Performance: Evidence from Zimbabwe (2009-2013)', International Journal of Economics and Financial Issues, 5(3), pp. 638-646.

Available at: http:\%5Cnwww.econjournals.com.

14. Kumar, P. (2017) 'Impact of earning per share and price earning ratio on market of share: A study on auto sector in India', International Journal of Research - Granthaalayah, 5(2), pp. 113-118. doi: 10.5281/zenodo.345456.

15. Luhukay, R. Mangantar, M. Baramuli, D. (2016) 'Saham adalah surat bukti atau tanda kepemilikan bagian modal suatu perseroan terbatas', Jurnal Riset Ekonomi, Manajemen, Bisnis dan Akuntansi, 4(5), pp. 501-510.

16. Manoppo, C. P. (2015) 'the Influence of Roa, Roe, Ros, and Eps on Stock Price', Emba, 3(4), pp. 691697.

17. Mgammal, M. H. H. (2012) 'The Effect of Inflation, Interest Rates and Exchange Rates on Stock Prices: Comparative Study Among Two Gcc Countries', International Journal of Finance and Accounting, 1(6), pp. 179-189. doi: 10.5923/j.ijfa.20120106.06.

18. Mulyani, N. (2014) 'Analisis Pengaruh Inflasi, Suku 
Bunga, Nilai Tukar Rupiah, Dan Produk Domestik Bruto Terhadap Jakarta Islamic Index An Analysis Of The Influence Of Inflation, Interest Rates, Rupiah Exchange Rate, And Gross Domestic Product On The Jakarta Islamic Index', Jurnal Bisnis dan Manajemen Eksekutif, 1(10).

19. Nurhakim, Anistia S. Yunita, Irni. Iradianty, A. (2016) 'the Effect of Profitability and Inflation on Stock Return At Pharmaceutical Industries At Bei in the Period of 2011-2014', Asia Pacific Journal of Advanced Business and Social Studies, 2(2), pp. 202-210.

20. Purnamawati, I. G. A. (2016) 'The Effect of Capital Structure and Profitability on Stock Price (Study of The Manufacturing Sectr In Indonesia Stock Exchange)', International Journal of Business, Economics and Law, 9(1), pp. 10-16.

21. Saragih, J. L. (2018) 'The Effects of Return on Assets ( ROA ), Return on Equity ( ROE ), and Debt to Equity Ratio ( DER ) on Stock Returns in Wholesale and Retail Trade Companies Listed in Indonesia Stock Exchange', International Journal of Sciene and Research Methodology, (3).

22. Setiawan, C. and Oktariza, H. (2013) 'Syariah and conventional stocks performance of public companies listed on Indonesia Stock Exchange', Journal of Accounting, Finance and Economics, 3(1), pp. 51-64.

23. Shuangqun, L. (2017) 'Research on the Relationship between Interest Rate and Stock Price in China', International Journal of Science and Research (IJSR), 6(7), pp. 2093-2099.

doi: $10.21275 / 27071710$.

24. Sugiyono (2012) Metode Penelitian Kombinasi (Mixed Methods). Bandung: Alfabeta.

25. Suparningsih, B. (2017) 'Effect of debt to equity ratio (DER), price earnings ratio (PER), net profit margin (NPM), return on investment (ROI), earning per share (EPS) In influence exchange rates and Indonesian interest rat es (SBI) share price in textile and garment industry Ind', International Journal of Multidisciplinary Research and Development, 4(11), pp. 58-62. doi: ISSN: 2349-4182.

26. Suriani, S. Kumar, M. D. Jamil, F. Muneer, S. (2015) 'Impact of Foreign Exchange rate on stock prices', International Journal of Economics and Financial Issues, 5, pp. 385-388. doi: 10.9790/487X-0734551. 